\title{
Chapter 11 Empowering Multilingual Learners Through Critical Liberating Literacy Practices in English-Dominated Speech Communities
}

\author{
Mario R. Moya \\ (iD) https://orcid.org/0000-0002-7445-8829 \\ University of East London, UK
}

\begin{abstract}
This chapter explores the nuances of critical literacy reviewing the influence of the sociocultural context and the critical element that arises from the individuals who negotiate their identities as they interact with others in a variety of settings. The perspective adopted here focuses on multilingual learners as they engage in literacy practices in English, the dominant language, within schooled environments resulting in hybrid productions within a Third Space, which is a metaphorical setting that promotes expansive learning. Such literacy productions consider the lived-in experiences of the individuals and their personal histories as tools for learning with the potential to liberate themselves from the dominant literacy practices. The chapter includes a discussion of the role and status of English to empower non-dominant groups within English-speaking settings.
\end{abstract}

\section{INTRODUCTION}

Literacy is often viewed as a complex process that is very challenging to define. In 1989, James Gee concluded that this concept encompasses much more than the mere knowledge of letters and sounds and, consequently, proposed that literacy, as solely the application of alphabetic knowledge, was quite 
narrow. Gee (2015) maintains that the concept of literacy needs to acknowledge its complexity, the purposes of the people who engage with it, and the contexts where literacy practices happen. In line with Gee, other researchers, such as Street (1984), Dyson (2001), and Brandt (2001), also highlight the intricacies of a definition. Street's (1984) research, for example, indicates that an exclusive focus on the application of the alphabetic principle to define literacy is restrictive. While this alphabetic knowledge is still very important, contemporary research from Barratt-Pugh (2002) and Brandt and Clinton (2002) expand the concept of literacy by focusing on how individuals' interactions at home, school, or other community settings contribute to an understanding of the uses, the power, and the need for literacy as a social practice. From this position, literacy is a social tool used by individuals in their daily life shaped by people's socio-cultural experiences. As Hammer (2005) explains "[the] socio-cultural view of literacy emphasizes the role literacy plays in today's society and supports children to actively take part in and access a wide range of social and cultural activities" (p. 71).

Literacy, in its most basic sense, refers to communication involving the use of written language. Reading and writing are recognizable literacy activities; however, perspectives on what is meant by literacy and what it means to be literate vary according to the particular traditions that researchers or policy makers draw on. Studies of literacy have been carried out within various academic disciplines — notably psychology, applied linguistics, anthropology, sociolinguistics, and education. Not surprisingly, studies from such a range of academic disciplines focusing on different aspects have given rise to rather different conceptions of literacy. Most obviously, literacy studies are characterized by:

- A focus on the individual's perceptual and cognitive functioning (within psychology);

- A focus on the analysis of written texts and the use of such analysis for the teaching of reading and writing (within applied linguistics);

- An interest in the observation and documentation of literacy activities in everyday life, emphasizing the social contexts of literacy (within anthropology and, increasingly, sociolinguistics);

- An interest in researching ways in which children and adults learn to read and write (within education).

The debate on the definition of literacy is mostly centered on the positions of those who advocate a code-based approach to teaching reading and writing and those who emphasize the place of meaning. Such a distinction has led to two dominant positions or models out of several, namely the autonomous and the ideological (Damber, 2012), where the former is associated with a set of cognitive skills (Cook \& Klipfel, 2015) whilst the latter sees literacy as embedded in social practices (Street, 2013). The autonomous model considers that literacy itself has consequences irrespective of, or autonomous of, context while the ideological model argues that literacy not only varies with social context and with cultural norms but with discourses regarding, for instance, identity, gender, and beliefs, and that its uses and meanings are always embedded in relationships of power. Street (2013) argues that it is in this sense that literacy is always ideological — it always involves contexts over meanings, definitions and boundaries, and struggles for control of the literacy agenda. It is this latter aspect that this chapter explores, emphasizing critical literacy in relation to its socio-critical and cultural aspects focusing on a metaphorical place called the Third Space (Guitiérrez, 2008) where individuals coming from nondominant linguistic backgrounds are empowered through liberating literacy practices based on their lived experiences to develop their own voices. The chapter, therefore, aims to: 
Empowering Multilingual Learners Through Critical Liberating Literacy Practices in English-Dominated

1. Review the autonomous and the ideological models of literacy as traditionally discussed in the literature with a focus on implications for teaching and learning practices.

2. Consider the main tenets of functional and critical literacies with a focus on the former in relation to multilingualism in speech communities where English is the dominant language.

3. Explore the nuances of critical literacy in relation to aspects of culture and criticality for teaching and learning English as a foreign or second language.

4. Review the theory of socio-critical literacy and the metaphors of the Third Space and zones of contact as a form of expansive learning to apply them in classroom contexts.

\section{THEORETICAL BACKGROUND}

Given the complexity surrounding the definition of literacy, researchers have traditionally focused their attention on explaining the purposes underpinning the uses that people make of literacy. One of these approaches is based on the knowledge of a set of sounds and a script used to record them. To be considered literate, individuals need to have a fairly good knowledge of how to transcribe sounds (writing) as well as to link the script to particular sounds to interpret them (reading). Literacy is, therefore, essentially a cognitive process (Olson \& Torrance, 2017). Critiques to the autonomous model focus on the fact that literacy is not a single phenomenon because individuals deploy a variety of skills depending on the social contexts and situations where they use literacy. In this sense, the researchers supporting this view indicate that it is more adequate to talk about literacies and of literacy practices as this terminology offers a more accurate perspective of the social nature of literacy. This view has given rise to the ideological model since literacy practices are never neutral as they are embedded with and in particular ideologies. The following sections review both models.

\section{The Autonomous Model of Literacy}

The autonomous model views literacy as a set of universal technical skills, the same everywhere, which is normally linked with the type of practice taught and developed in schools underpinned by a cognitive approach whereby children learn a set of reading and writing skills based on a phonetic relationship involving the transcription of sounds into a given script. The research carried out within this model has traditionally focused on the way in which individuals decode texts and has included, for instance, studies on readers' eye movement when scanning a page (White et al., 2015), and others investigating the psychological and perceptual processes involved in reading (Whiteford \& Titone, 2016). More recently, the type of research underpinned by a cognitive perspective includes the study of sense-making strategies that readers use to comprehend text, and how children learn to use alphabetic and other scripts (Perfetti \& Harris, 2017). Research in this domain has been very useful in investigations into dyslexia and other specific language processing difficulties that influence the design of assistive technology, including computer-mediated programs used for teaching reading. The autonomous perspective considers that the script provides the model for thinking about the sound structure of speech. This has serious implications for teaching of literacy as there is a theoretical position that argues that becoming literate has specific and profound effects on ways of thinking, both for society and individuals. However, Olson (2017) claims that literacy is connected to a particular way with words, their meanings, and their roles in expressions rather than the ability to inscribe. Wray (1997) also argues that "it is the process of beginning to learn 
to read that draws the child's attention to letters, sounds and their relationships, enabling the insight which unlocks the system" (p. 2); however, formal learning of the phoneme/grapheme relationship - or phonics - is not enough: learners also learn through practice and use. With this assertion, it is possible to see a shift in paradigm that brings about the social element of literacy.

\section{The Ideological Model of Literacy}

The ideological model is underpinned by the New Literacy Studies, which is a collection of research about the language and social theory known as social literacies and the dialogic nature of language (Street \& Lefstein, 2007). In relation to the former, one of the premises of this model rests on the idea that learning to read and write is not simply a cognitive process based on phonetic relationships or the use of a script to transcribe sounds, but it is indeed much more encompassing as literacy occurs naturally in social life, taking into account the context and different meanings that literacy has for different cultural groups. An implication of this view is that individuals are exposed to a plurality of literacies which vary according to social settings. The ideological model, therefore, not only argues that literacy varies with social context and with cultural norms and discourses regarding identity, gender, and belief, but also that the uses of literacy and its meanings are always embedded in relations of power. However, some proponents of the New Literacy Studies do not agree with the notions of multiple literacies since this concept implies some stability which is seen as a paradox that some researchers reject (Cope \& Kalantzi, 2000).

Whilst Street (2017) considers that for strategic reasons, different world agencies "present literacy as the panacea to social ills and the key ingredient to modernization, the dominant assumption has been of a single autonomous literacy that is the same everywhere and simply needs transplanting to new environments" (p. 25). However, given the dynamic and culturally varied quality of literacy practices, it is more accurate to speak of a plurality of literacies. The term literacy practices is of vital importance within the New Literacy Studies circles as it refers to the specificity of cultural practices with which reading and/or writing are associated in given contexts. The term also acknowledges that within a given cultural domain there may be many literacy practices rather than one culture, one literacy. In this sense, Street (2017) argues that literacy practices not only refer to observable behaviors around literacy, but also the concepts and the meanings brought to those events which give them meaning. This perspective has paved the way for a type of research into literacy practices from the point of view of ethnography, characterized by flux, ambiguity, and uncertainty because of the diverse nature of literacy practices. One of the earliest examples of this type of research was carried out by Prinsloo and Breier (1996) in South Africa, focusing on the everyday literacy practices of people in the Cape area. Similar studies abound in the contemporary research, particularly those exploring literacy practices in different environments, especially home and school, though not exclusively (Alston-Abel \& Berninger, 2018; Nash et al., 2018; Nag et al., 2019; see also Farrelly \& Fahkrutdinova in this volume).

The models reviewed above have contributed to the development of different assumptions or theoretical postulates that help us see literacy from particular viewpoints which are summarized below, and which have contributed to the emergence of some teaching and learning practices. Whilst the first framework (i.e., functional literacy) emerges directly from the autonomous models, the others (i.e., cultural literacy and critical literacy) are further developments of the ideological model, where the main purpose is to question the ideas and beliefs upon which certain literacy practices are enacted in society. Since the focus of this chapter is on critical literacy, the topic of functional literacy is only briefly introduced to provide background information. 
Empowering Multilingual Learners Through Critical Liberating Literacy Practices in English-Dominated

\section{Functional Literacy}

The acquisition of knowledge of how to code and decode texts to achieve practical aims through the skills of reading and writing is the fundamental basis of functional literacy. In response to a lack of literacy skills amongst a large percentage of the population in developing countries, Gray (1956) coined the term functional for the United Nations Educational, Scientific, and Cultural Organization (UNESCO) to refer to the training of children and adults to "meet independently the reading and writing demands placed on them" (p. 21). At the time, literacy experts were concerned that the teaching of literacy in developing countries was focused solely on skills and needed a greater focus on practices. According to Comings (2019), this concern led to UNESCO's emphasis on literacy as a functional skill, and literacy instruction consistent with this approach was referred to as functional literacy. The purpose of functional literacy is a basic one (Graff cited in Verhoeven, 1994, p. 40), and it refers to a level of reading and writing that are sufficient for everyday life (Egbo, 2000). In many countries, this framework refers to the process and content of learning to read and write in the preparation for work and vocational training, as well as for increasing the means of productivity. Egbo (2000) argues that functional literacy is necessary to facilitate reading and writing to enable people to participate in the social, economic, and political processes for the betterment of their lives and for social change, and it is the type of literacy associated with school practices.

From a global perspective, Rassool (1996) indicates that reading and writing can be quantified and, as such, results can be compared against economic outcomes criteria. Research following this perspective are largely focused on correlations between levels of functional literacy, education, employment, and age in the population, amongst other variables, which also indicate the characteristics of individuals with low literacy levels (Rabušicová \& Oplatková, 2010). This framework is followed by international agencies, such as UNESCO and the Organization for Economic Cooperation and Development (OECD) through the PISA reading performance test, which "measures the capacity to understand, use and reflect on written texts in order to achieve goals, develop knowledge and potential, and participate in society" (OECD.org, 2019). In contrast, Levine (1982) notes the importance of the cultural and socioeconomic context when determining the nature and value of literacy, which he describes as a "positional good" (p. 259) that has value in terms of social status and not just utility. According to Burgess and Hamilton (2011), Levine's view prefigures the approach to literacy as a socio-cultural practice which was beginning to be articulated at that time (see Scribner and Cole, 1981; Heath 1983; Street, 1984) and has since become established as the New Literacy Studies (see Barton and Hamilton, 1998; Barton, Hamilton and Ivanič, 2000; Gee, 2015; Brandt, 2001; Street, 2001).

\section{Critical Literacy}

Critical literacy is an instructional approach stemming from Marxist critical pedagogy (Luke, 2012) that advocates the adoption of "critical" perspectives toward text (Gee, 2015) as a response to the oppressive classroom practices based exclusively on the acquisition of mechanical reading and writing skills. Critical literacy encourages readers to actively analyze texts and offers strategies for what proponents describe as uncovering underlying messages (Ochoa et al., 2018). Two key proponents of this approach are Macedo and Freire (1987) who argue that those who are critically literate can not only understand how meaning is socially constructed within texts but can also come to understand the political and economic contexts in which those texts were created and embedded. In action, Macedo and Freire employed critical literacy 
to address the social and geographical needs of marginalized communities while developing community members' literacy skills. There are several different theoretical perspectives on critical literacy that have produced different pedagogical approaches to teaching and learning (McDaniel, 2006). All of these approaches share the basic premise that literacy requires the literate consumers of text to adopt a critical and questioning approach (Higgins, 2009). In the following section on practical applications, critical literacy is discussed in relation to multilingualism, cultural literacy, and socio-critical aspects in settings where minorities operate in English dominant spaces.

\section{English and Non-Dominant Literacies}

The status of English as a lingua franca brings with it a series of connotations that considers language as a commodity to access symbolic goods, aiding individuals' self-actualization, to positions denouncing that English encourages the displacement of minority languages and their corresponding literacy practices (Phillipson, 2013). This latter view sees English as a form of cultural colonization which imposes dominant alien values and practices over nondominant groups. The inability to use English has been a debate in the United Kingdom as well as in other English-speaking countries where people who are not competent in the dominant language are, by far, singled out as illiterate, an assumption that does not take into consideration that those individuals may be literate in one, or maybe more, languages. The teaching of English to speakers from different linguistic backgrounds in a cross-cultural context, as Pennycook (1994) argues, is not simply teaching language facts, but teaching a way of living and a mode that can subvert their native identities.

For a long time, certain literacy practices in nondominant languages have been discouraged within schools with a stringent policy of English-only in many countries in the world. Anything incompatible with the dominant or official discourse in such contexts is considered atypical and, as a result, unofficial voices are suppressed, and multivocality is silenced (Qu, 2011). On the other hand, English is seen as a weapon for self-actualization and social development, leading Pennycook (2008) to argue that English "is always a language in translation, a language of translingual use" (p. 34). These views are in direct relationship with Gee's (2015) characterization of Primary and Secondary Discourses, where he uses the term Discourse to mean "ways of being in the world" (p. 21) - that is more than just language, but ways of displaying membership to particular social groups. Therefore, it is not uncommon to hear nonnative speakers of English indicating that they live in a linguistic duality in English-speaking countries: whilst English, the Secondary Discourse, is the language of schooling, the individuals' mother tongues, or Primary Discourse, are used in other settings or communicative situations within their own linguistic communities. Since individuals move from home to school, they move from familiar domestic worlds which are part of their primary socialization to take on other identities, ways of behaving, and ways of using language. In this sense, Gee (2015) argues that "literacy is mastery of, or fluent control over, a Secondary Discourse" (p. 153). These perspectives are not neutral as they point to another reality within the field -to use Bourdieu's terminology (Bourdieu, 1990) of language as a social and cultural commodity: languages are perceived to have a higher status $(\mathrm{H})$ as opposed to the ones that do not, also known as (L) languages, where L stands for lower status, each with their corresponding practices.

Various studies have examined what may be seen as lower status and higher status literacy (Street, 2001). According to Ferguson's (1959) categories "H languages are prestigious, learnt formally and used formally while L languages are acquired at home and used in informal situations" (Barrett, 1994, p. 5). In a western migrant situation, lower status literacy may be that assigned to literacy skills in managing the 
Empowering Multilingual Learners Through Critical Liberating Literacy Practices in English-Dominated

household (domestic) whilst higher status literacy may be that offered by college courses (Street, 2001). Domestic literacies would be trivialized whereas literacies that increase job opportunities are intrinsically more valued. The implication of views such as these is that English as a lingua franca is seen as offering a platform for the development of higher status literacies whereas indigenous languages, despite their intrinsic wealth, continue to perpetuate a lower status (Kashina, 1994). Rassool (1999) asserts that the relative value attached to particular languages in national policy may derive from dominant ideas about what constitutes the nation and may be directly related to cultural, economic and linguistic factors. In turn, Street (2001) suggests that in such instances, the dominant literacy may be presented as one that facilitates "access to power and exclusion from it" (Blanc \& Hamers, 2000, p. 222). It is not surprising, therefore, that English as the lingua franca has such an intrinsic power.

Teaching English as a foreign or as a second language - or any language - has traditionally followed the autonomous model as an ideology-free literacy. The "ideological model," on the other hand, sees English language teaching and learning as practices involving values, risks of identity change, and other complicated social concerns, because English as a value-laden language forces its idiosyncratic values upon its learners. However, embedding English teaching in a social context does not mean rejecting all the values it carries with it or lead to seeing English literacy in terms of identity politics. Gee (2015) offers a constructive approach: "We can also talk about a literacy being liberating ('powerful') if it can be used as 'meta-language' or a 'meta-discourse' (a set of meta-words, meta-values, meta-beliefs) for the critique of other literacies and the way they constitute us as persons and situate us in society" (p. 177). The implication of such a view is that there is no English teaching approach immune to ideologies and the topics we teach in English, based on the lived experiences of the learners, have a potential to empower individuals to develop an active role in society where they are a minority.

\section{Multilingualism}

Although multilingualism and multilingual education are not new phenomena, our emergence into the 21 st century has brought some renewed interest and contestation around them. Ethnolinguistic diversity and inequality, intercultural communication and contact, and global political and economic interdependence are more than ever acknowledged realities of globalization, adding new demands to educational systems around the globe. Now, as throughout history, as De Costa (2016) claims, multilingual education offers the best possibilities for preparing students to participate in constructing more just and democratic societies in a globalized and intercultural world; however, such an education is not unproblematically achieved. To understand multilingual education, it is necessary to consider three aspects related to multilingual, multicultural education: first, the multilingual perspective involves the use and the value of more than one language in teaching and learning; second, the intercultural perspective recognizes and values understanding and dialogue across different lived experiences and cultural worldviews; and third, an acknowledgement of the knowledge that students bring to the classroom encouraging their full and indispensable participation in society - locally, nationally, and globally (Coulmas, 2018). Opening up spaces for multilingual education, therefore, requires teaching and learning opportunities that take into account all languages in the ecology of multilingual students whilst recognizing that the language(s) they are involved in are situated in social spaces and contexts which may require a crossover of different literacy practices in their mother tongue(s) as well as in a dominant new language. This is the case, for example, of children who can operate fluently in Pashto, Urdu, and Punjabi who are learning English upon the belief that English will provide them with more and better prospects. 
Researchers, such as Pennycook (1998) and Phillipson (2007), argue that teaching English is a form of cultural colonization that imposes dominant alien cultural values and practices upon others that are disadvantaged for various reasons within a very competitive world. These scholars have challenged the de-ideologized neutrality of traditional English teaching practices, viewing English classes as contact zones where cultures meet, clash, and grapple with each other, often in contexts of highly asymmetrical relations of power, such as colonialism, slavery, or their aftermaths as they are lived out in many parts of the world today (Pratt 1991, p. 34). Such a reality points to a concern about other languages in an English-speaking setting as weapons of cultural threat which have arisen largely from identity politics that stresses exclusive group membership (Horner \& Lu, 2007). Identity politics, trading on cultural differences, defines anything different from self as the foreign or the other, characterized by a psyche of victimization and othering (Phillipson, 2007).

It is important to emphasize then that critical literacy studies, as a discipline rooted in critical theory, has contributed to the development of tools to re-conceptualize literacy as a subversive practice with the potential to empower linguistic minorities, break the monolingual silence, and challenge biases (see Duggan in this volume). In fact, literacy cannot be considered a static skill but should be seen as a set of multiple practices that vary across languages, cultures and contexts to empower individuals by enhancing their critical literacy skills. Some authors, including Gee (2015) and Street (2001) emphasize the situatedness of literacy practices and, as such, it is important to reflect on the sociocultural contexts where those practices take place. Whilst it is not a discrete entity separated from critical literacy, cultural literacy is a further aspect within the complexity of the latter that needs attention when discussing literacies and literacy practices in multilingual settings.

\section{Cultural Literacy}

Cultural literacy refers to the aspect of critical literacy that empowers nondominant groups to understand the nuances and overtones of the dominant linguistic group and negotiate strategies for them to function appropriately in such a group. However, cultural literacy may exist in tension. For instance, one view of cultural literacy may relate directly to the notion of linguistic competence. Bourdieu (1990) asserts that foreign language teaching should concentrate on equipping learners with the means of accessing and analyzing any cultural practices and meanings they encounter regardless of their status, a view also shared by Christensen (1994). These assertions are of particular interest where a foreign language and culture may often be perceived as invasive since it is often the case that Western practices may be seen to have an impact on the way individuals construct and deconstruct texts in society. This is not a new debate as it was first discussed in the United Kingdom back in 1987 when teachers asked the question: "Whose culture should we teach?" (Villegas 1988, p. 37).

Recent international studies have focused on critical literacy as situated in the context of post-apartheid South Africa (Janks, 2010), and in relation to place and space in the context of climate change in Australia (Comber, 2010). There have also been studies in Central and South America, for example in Mexico (Kalman, 1999) and Brazil where the work of Paulo Freire (1972) originated (Bartlett, 2005). Critical literacy pedagogies then aim at the interrogation of canonical texts, often from home and community settings, that then open up new spaces in which young people can draw on their funds of knowledge and cultural capital (Gonzalez, Moll, \& Amanti,2005; Lee, 2007; Morrell \& Duncan-Andrade, 2002; Richardson, 2006). This engagement with out-of-school texts can then offer Third Spaces where these literacies are valued alongside canonical texts, and young people's out-of-school literacy practices are 
Empowering Multilingual Learners Through Critical Liberating Literacy Practices in English-Dominated

recognized (Moje et al., 2004). The metaphorical aspect of a Third Space and the affordances they provide are explored later in the chapter. All the practical applications of critical literacy reveal the relevance and significance of textual interpretations in the broadest sense, the understanding of definitions and the ability to analyze texts and discourses beyond the technical skills involved in decoding words. Critical literacy is thus often regarded as inherently political because it challenges established readings, an assertion that finds echo in the work of Stables (2003), who argues that critical literacy is the ability to read socio-cultural practice through the study of texts, thus "allowing readers to gain some control over ideologies and socio-cultural practices" (p. 61). An example of this is presented in the teaching tip below.

Researchers have demonstrated that young children are quite capable of taking up issues of hegemony and representation (Dyson, 1989; Leland et al., 2005; Ryan, 2010; Wohlwend \& Lewis, 2011). Dyson (1989) was among the first to describe how young children resist dominant narratives to position themselves as agents in their own childhoods and uses the concept of remix to describe how children draw on literacy practices outside school and mixed them with in-school practices, using Bahktin's ideas that texts are dialogic and that literacy only empowers individuals when it renders them active questioners of the social reality around them (Bahktin, 1981). In so doing, Dyson (1990) acknowledges the intertextual nature of children's textual productions across sites while Phal and Burnett (2016) recognize the way in which "children's textual productions, despite being composed at school, seep outside into the worlds of home and community" (p. 4).

In relation to second language learning, Cummins (2001) acknowledges that effective instruction must focus initially on culture, meaning, and messages. He suggests that in order to engage students to their cognitive maximum and deepen their understanding of language and content, comprehensible input must be transformed into critical literacy (2001). In fact, he argues that instruction solely based on the development of learners' knowledge about the language creates a less easily detectable undertow of meaning, which appears to be a drawback of current bilingual teaching approaches. To put Cumming's ideas into a context, it is worth noting that large numbers of ethnic minority students in British schools have spent a significant proportion of their lives in Britain and use colloquial English with ease. Many of these students may have reached a plateau in which they do not seem able to make further progress in English. Current systems in education continue to identify such students as one-dimensional bilinguals speaking a minority language at home whilst learning English at school. These concepts may be of little help for teachers in developing adequate teaching approaches and strategies since it is necessary for them to rethink the romantic notion of bilingualism and take a more realistic look at what we call bilingual learners in face of the multilingual and multiethnic youth who inhabit a world where language, culture and ethnicity are fluid and change from generation to generation (Naldic, 2019). In this sense, it is interesting to note that Neal and Kelly (1999) argue that skills associated with critical literacies, for example critical thinking, are amiss because the emphasis of the instruction is mostly placed on the development of basic skills (i.e., reading, writing, speaking, and listening). This assertion seems to imply that teachers need greater awareness and training to be able to implement critical literacy instruction more effectively because, as Comber, Thompson, and Wells (2001) claim, teachers are usually left out of the debate on the value and purposes of literacy in the wider world.

When considering the practical aspects of doing critical literacy, Rassool (1999) explains that this demands skills, knowledge, and attitudes necessary for exploring and making informed decisions in a democratic society. Freire (1972) alludes to issues of the individual and identity in liberation struggles. Pennycook (1994), in turn, puts forward that critical pedagogy views schools as cultural and political arenas where different, cultural, ideological, and social forms are constantly in struggle. Scholars using 
critical literacy pedagogy have interrogated texts as sites of power imbalances and have argued that the process of reading texts critically can create shifts in understanding and social structures (Janks, 2010). In the same vein, Armour (2001) shifts the focus from the commonly held view of critical literacy as the interpretation of texts in the broadest sense to the ability of individuals to display responsible participation with others. This idea is in line with Street (1995), who argues that people should be allowed to manage their daily lives, intellectually, emotionally, practically, and economically without the elaborate definitions and distinctions associated with literacy and illiteracy in the west. For instance, a study by Parajuli and Enslin (1990) shows how women achieved critical consciousness through a literacy program whilst Gutiérrez (2008) explains how Latino students in a migrant center in California developed hybrid language practices by challenging traditional forms of academic literacy. In both studies, participants used their first language as a tool to negotiate meanings in English (languaging) with positive results. These examples show that functional skills that involve the day to day use may also create consciousness and challenge oppressive literacy practices by giving individuals back their own voices (Gutiérrez, 2008). Rather than reproducing stifled literacy models of schooling, learning outcomes and standards pushed down on them, the cultural dimension of literacy practices emphasizes individuals' agency beyond the school dimension while giving individuals an opportunity to liberate themselves from the school discourse and, instead, use their lived experiences to formulate their own curriculum shaped by relationships, spaces, narratives, and language (Olson, 2000).

\section{Socio-Critical Literacy}

A major tenet of critical literacy, as reviewed above, is its situated nature. Street (2013) argues that the term situatedness allows us "to specify the particularity of cultural practices with which uses of reading and or writing are associated in given contexts. Within a given cultural domain there may be many literacy practices, i.e. not one culture and one literacy" (p. 34). Street goes on to explain that literacy practices are not only observable behaviors around literacy, but also the concepts and the meanings brought to those events and which give them meaning. This argument is very interesting in so much as it challenges an exclusively Western understanding of literacy that Gregory and William (2000) develop in their account of distinctive literacy practices of language minority children and for their teaching implications in the mainstream. Traditionally, an autonomous view of literacy has taken for granted that classroom literacy instruction is constructed and practiced as neutral technology (Street \& Street, 1995), favoring a view of literacy as involving the unproblematic teaching of skills, with little contextualization of practice, and little acknowledgement of the distinctly different literacy experiences that bilingual learners may have in their linguistic repertoire. In this sense, Wallace (2002) indicates that "the job of educators is to acknowledge the differences, to build bridges between the domains of school and everyday life" (p. 54).

This stance on literacies and their different domains, especially those of bilingual children, has been discussed by Gutiérrez (2008) who explains that such experiences emerge from meaningful classroom practices that include the students' vernacular to empower minority linguistic groups. He uses the metaphor of a Third Space, which he describes as the social environment for development in which students begin to reconceive who they are and what they might be able to accomplish academically and beyond. In other words, this perspective looks at the individuals, their identities, their aspirations as well as their own views of the world, acknowledging their linguistic capital as factors contributing to their academic achievement thus subverting the English-only, one-size-fits-all curricula. Gutiérrez (2008), when highlighting the importance of the students' identity - an agentive process - introduces the 


\section{Empowering Multilingual Learners Through Critical Liberating Literacy Practices in English-Dominated}

concept of historicity into the discussion to refer to the students' lived literacy experiences in everyday life as well as in school to frame them into powerful literacies oriented towards critical social thought. This is what he calls socio-critical literacies whose distinguishing feature is its attention to contradictions in and between texts lived and studied, institutions (i.e., classrooms), and social practices, locally experienced and historically influenced.

The views on socio-critical literacies as discussed by Gutiérrez (2008) are essentially based on Berstein's (1999) vertical and horizontal literacies. The latter are segmental and embedded in ongoing practices and directed to specific goals and are often acquired through apprenticeship whilst the former is scaffolded in schools and learned rather than acquired or picked up on the job. Street and Street (1995) argue that "it is not that school literacies are inferior attempts at 'the real thing', but they are qualitatively different" (p. 106). Wallace (2003), for instance, argues that schooled language, which is literate-like rather than necessarily delivered through the medium of print is a code for learning and for wider communication rather than for day-to-day use. Nor is it the case that primary knowledge, including, most importantly, knowledge of home languages and literacies, is to be discarded; rather, it is rearticulated among a greater diversity of voices and experiences, which accompany the move into socialization. Gutiérrez (2008) posits that the importance of historicity as this notion demonstrates an alignment with cultural-historical approaches to learning and development whereas school-based literacies generally emphasize ahistorical and vertical forms of learning. When Wallace (2003, p. 46) talks about "a greater diversity of voices and experiences," she is tapping into Gutiérrez's idea of the Third Space, which she sees it as a hybrid space emerging from both vertical and horizontal forms of learning thus giving students wider repertoires of literacy practices. Such repertoires include not only what students learn in formal learning environments, such as schools, but also what they learn by participating in a range of practices outside school.

The Third Space that Gutiérrez (2008) talks about can be seen as an instance of expansive learning. Traditionally, change has been defined along a vertical dimension, moving, for example, from immaturity and incompetence to maturity and competence (Engeström, 1996). A more expansive view of development is concerned with the horizontal forms of expertise that are developed within and across an individual's practices and how students negotiate the significant overlaps across boundaries as people, tools, and practices travel through different and even contradictory contexts and activities. It is from this perspective that we begin to understand the cultural dimensions of learning and development that occur as "people, ideas, and practices of different communities meet, collide, and merge (Engeström 2005, p. 46). In everyday life, people live their lives and learn across multiple settings, and this holds true not only across the span of their lives but also across and within the institutions and communities they inhabit. The Third Space, therefore, means differences in involvement, participation, and learning of students in classroom instructional activities within multiple social spaces with distinctive participations and power relations. Gutiérrez (2008) concludes that:

[T] he use of the Third Space construct has always been more than a celebration of the local literacies of students from nondominant groups; and certainly more than what students can do with assistance or scaffolding; and also more than ahistorical accounts of individual discrete events, literacy practices, and the social interactions within. Instead, it is a transformative space where the potential for an expanded form of learning and the development of new knowledge are heightened (p. 152).

To summarize, a socio-critical literacy is a syncretic literacy organized around a pedagogical approach that focuses on how individuals and their communities influence and are influenced by socio-political and cultural discourses and practices in historically specific times and locations (Cruz, 2006), offering a 
historicized view of the students' own socio-cultural situation whilst rejecting the traditional mismatch theories of home-school discontinuities. Such frameworks reinterpret the deficit portraits of home that compels educators to act to fix communities and their members so that they match normative views and practices without regard to the students' existing repertoires of practice (Gutiérrez \& Rogoff, 2003).

\section{CLASSROOM APPLICATIONS}

While there are various approaches and techniques for developing critical literacies in the classroom, a pragmatic perspective has been adopted in this chapter since different settings require different techniques. With this in mind, two frameworks have been used to illustrate how to develop critical literacy practices in the classroom, namely, McLaughlin and Allen's (2002) and Janks's (2010). When combined, these frameworks provide a practical guidance to develop different skills to enable learners to read beyond the printed word and for teachers to create contexts for critical literacy to flourish. One distinguishing feature of both frameworks is the emphasis on access, a concept understood as opportunities that are available to individuals through their engagement with literacy practices. As a socio-critical approach requires learners to negotiate their identities and imbalances in power relations in zones of contact, it is important to consider the following three stages to facilitate such negotiations: 1 . activation of prior knowledge, 2. problem posing, and 3. evaluation of own perspectives, beliefs, and attitudes.

\section{Activation of Prior Knowledge}

A fundamental premise of the socio-critical approach to literacy rests upon the belief that learners' lived experiences are, indeed, the real curriculum (Vickery, 2016). This statement has profound implications as it postulates that learners already possess a wealth of knowledge and experiences they can build upon as they encounter new learning. By facilitating the activation of prior knowledge, teachers can use learners' life experiences to make links between a topic in the subject curriculum and their own personal narratives. Such links can intrinsically increase learners' engagement and motivation while creating the right atmosphere for learning.

The activation of prior knowledge can be prompted through a variety of techniques. The most frequent is the use of graded questions ranging from yes/no items to others with a much wider scope inviting learners to share personal narratives. The teacher should steer the learners' responses so that these align to the learning objectives of a lesson. In teaching groups where there are migrant students or those whose linguistic background is different from the national language, minimum proficiency in this language should not be seen as a communicative barrier. In this case, these learners should be encouraged to use their first language(s) and use other peers speaking the same language(s) to provide a translation.

For example, a teacher can gauge how much their students know about the topic of worldviews before introducing the theme through the poem The blind men and the elephant (Saxe, 1863). By using questions, the teacher can ask students to jot down their ideas on a piece of paper as this will help learners to trace their understanding of the concept of worldwide as the lesson progresses, which can be used again at the end for the purpose of self-assessment.

Alternative techniques to activate prior knowledge include the K-W-L chart. Students write and share what they already know about the topic in the K (What I Know) section. They then add questions in the W (What I Want to Know) section and write their learnings in the L (What I Learned) section as they 
uncover new information through written and digital texts. This can be a powerful resource to monitor how learners' perceptions, ideas, beliefs, and positions have changed throughout the lesson. These charts can be useful to monitor students' learning and to gauge the impact of the lesson which, from the point of view of critical literacy, should aim at challenging students' taken-for-granted perspectives.

\section{Problem Posing}

Critical literacy is based on the idea that no text is neutral (Janks, Dixon, Ferreira, Granville, \& Newfield, 2014). In fact, Janks et al. (2014) argue that texts are partial since they cannot capture the world as it is. In practice, this means that texts only offer a part of a story and that they reflect the point of view of the text producer. In this sense, partial is the opposite of impartial. Learners should be guided to develop a critical awareness by learning how to read beyond the written word to capture the totality of meaning and consider such aspects as language and power, discourse and power, and diversity and inclusion (or exclusion). This can be achieved by guiding learners' thinking through a series of prompts, which can include the following questions:

- Who is in the text/picture/ situation? Who is missing?

- Whose voices are represented?

- Whose voices are marginalized or discounted?

- What are the intentions of the author? What does the author want the reader to think?

- What would an alternative text/picture/situation say?

- How can the reader use this information to promote equity?

The use of denotation and connotation usually facilitates the development of critical awareness. For example, the poem The blind men and the elephant (Saxe, 1963), at a surface level, can be analyzed in relation to a particular textual genre containing particular literary devices; however, from a more critical perspective, it is possible to interpret that individuals see the world from different perspectives depending where they are positioned. A person may be educated or uneducated, liberal or conservative, rich or poor, nonbelieving or God-fearing, but all people act and live in certain ways because they are guided by particular worldviews.

An alternative technique includes the use of reflection through Connection Stems. These are prompts that provide a structure to make connections while reading narrative and informational texts. Examples of Connections Stems include the following:

- That reminds me of...

- I remember when ...

- I have a connection ...

- An experience I have had like that ...

- I felt like that character when ...

- If I were that character, I would ...

- I remember another book about this ...

When sharing their completed Connection Stems, learners use text support and personal experiences to explain connections or to problematize pieces of information. 


\section{Evaluation of Own Perspectives, Beliefs and Attitudes}

When learners engage in critical literacy practices, their views are constantly challenged as they grapple with different conflicting perspectives. Janks et al., (2014) talk about redesign to refer to the internal and external processes that take place when individuals immerse themselves into the life of texts. In fact, Christensen (2006) argues that critical literacy "equips students to engage in a dialogue with texts and society instead of silently consuming other people's words" (p. 385). To be able to achieve this dialogue, learners should be able to evaluate and re-evaluate their positions constantly and act upon their new perspectives which emerge as a result of their active involvement with texts.

As critical literacy is linked to social justice (Comber, 2015), action is key to show how such a dialogue unfolds to create a more equitable society and empower individuals. A good way for learners to take action on different social issues is to encourage them to record their views prior, during, and after a lesson where competing views are presented. For this purpose, the K-W-L chart, as explained earlier, can be a very effective resource. Other alternative options include the use of reflective diaries or more creative resources, such as plays, music, and art, where learners are given an opportunity to express themselves.

For example, as a concluding technique for the lesson on worldviews, learners can be asked to produce a drawing or a collage or even perform a short play based on the characters in the poem The blind men and the elephant (Saxe, 1863) since activities such are these this will certainly help to reinforce the learning that has taken place in the lesson.

Additionally, the technique of switching, where learners are encouraged to put themselves in someone else's shoes, does not only develop empathy but also prompts learners to see the world from different positions so that they can re-evaluate their believes and attitudes according to different roles. There are many variations of this technique; for example, gender, theme, setting, body-style, clothing, emotion, ethnic/race, language, and relationship/organization switching (see DeVoogd \& McLaughlin, 2004, for further examples). Encouraging students to delve into the different meanings encapsulated in texts will certainly help them to become more aware of a multiplicity of worldviews.

\footnotetext{
Teaching Tip

John is a newly qualified teacher who works in a school in the outskirts of a major city in the United Kingdom. The composition of his teaching group in an upper primary school reflects the population diversity of the local area. John has identified that his students tend to retreat and group with peers sharing the same cultural and linguistic backgrounds and, as such, they find it difficult to blend, thus creating many isolated subgroups within the classroom. In order to enable students to mingle, John decided to implement a small crosscurricular project to introduce the idea of 'otherness' as an attempt to get his students to develop an awareness of how different points of views influence the way people conceive the world and also other people. The overarching theme of this project is immigration, as most of the learners are newly arrived students. The project also seeks to address stereotypical views with the goal of fostering community integration and the elimination of communicative and other types of barriers in his classroom.

John hopes that this project will contribute to the development of children's empathy by challenging their ways of thinking about one another (most of whom are new to the country) and usually portrayed as having special language needs by the school. For this purpose, John has collected a variety of text (printed and audiovisual ones) for the learners to engage with. The task, therefore, aims at exploring how people develop ideas about others by discussing language and power relations exercising what Freire (1972) calls "critical consciousness" (p. 52), a way of thinking about personal literacies that engages learners in empathy and compassion, in living lives as change agents. The task includes input from the following school subjects:

- Geography: Knowledge of the world, countries, migration and displacement;

- History: Formation of nation states, current affairs influencing people's lives;

- English: Elements of argumentative and persuasive speech/writing;

- Modern Languages: The self, description of family life with an emphasis on cultural knowledge;
} 
Empowering Multilingual Learners Through Critical Liberating Literacy Practices in English-Dominated

\begin{abstract}
Teaching Tip
- Mathematics: Interpretation of statistical information to make comparisons;

- Drama and Art: Focus on empathy by acting out different feelings and by representing migrants or displaced people's feelings through a collage;
\end{abstract}

- Personal, Social, and Health Education: Integration of migrant groups to the society, sense of belonging, loss and struggle for survival.

John begins the lesson with a video sequence of five children talking about their experiences of leaving their countries and relocating in the United Kingdom. Different situations are illustrated in the video sequence; for instance, asylum seeking, the refugee experience, economic migration, and sojourners' experiences. This is an introductory activity aimed at developing students' awareness of the different socio-political situations and contexts that prompt people to leave their home countries to seek new opportunities in other parts of the world, using their personal narratives as the main curriculum. This activity is expected to contribute to the creation of an atmosphere for the students to begin to question their own perceptions about otherness while encouraging them to think about one another in a more positive manner.

As the children watch a video clip, there are prompts for reflection about how some migrant children have been portrayed by mass media, with newspaper clips arranged in different parts of the classroom, which they will use as part of some writing tasks. John uses questions to trigger learners' views and encourages the newly arrived students to share their views using their own home languages with other children translating into English or using the technique of translanguaging to give them a voice. This experience is expected to help all learners to develop and consolidate learning in the Third Space' (Gutiérrez, 2008) while challenging dominant narratives that successful learners are the ones who can speak English.

John decides to follow the above activity with a discussion introduced by the question: What if our ways of looking at the world were upside down? This task is aided by the an upside down map (https://map-centre.com.au/wp-content/uploads/2017/07/Upside-DownWorld-Wall-Map.png) with the title "Change your perspective" displayed on the board. The activity aims at engaging students in the exchange of perceptions about the imagined north and what this represents for them.

John requests the learners to re-arrange the layout of the classroom to enable group discussions which will help them to complete a series of brief literacy and numeracy tasks consisting of a comparison of statistical information regarding, among others, number of inhabitants in the countries where they come from, percentages of languages spoken in the world, and how many languages are represented in the classroom. This activity is meant to promote a discussion about opportunities and inequalities by comparing and discussing facts about the North and the Global South, bringing learners' personal histories, developing dialogic learning, and valuing oracy as a form of literacy-as-event, which Burnett and Merchant (2018) define it as a heuristic for thinking with the fluid and elusive nature of meaningmaking where an event is generated as people and things come into relation.

For the last part of the project, John decides to use a creative way of assessing students' knowledge by asking learners to plan and carry out a creative production (either a small role-play situation, a collage, or a piece of music) to be performed to the rest of the group. Given the topics covered previously, John expects that the students will display issues concerning struggles of acceptance and of asymmetric power relations between the dominant language and their home language/s, tensions between academic practices in schools and at-home, cultural clashes, and their wishes in relation to the use of the English language for their future aspirations, among others. While all these topics are essential, John ensures that all the learners in his class are fully engaged with a role to play regardless of home language, cultural background, or proficiency in English. This part of the task is underpinned by the metaphor of the English class as a zone of contact, i.e., a social space where cultures meet, clash, and grapple with each other, often in contexts of highly asymmetrical relations of power (McKey, 2002).

\title{
CONCLUSION
}

The chapter explored some of the nuances involved in the view of literacy as a social practice embedded in the cultural and the socio-critical domains whilst considering aspects of multilingualism and the teaching of English as a lingua franca within a framework of critical literacy. The aim of literacy education has generally come to be understood as the development of critical (rather than functional) literacy, specific to one form of activity or social practice. It is generally understood that critical literacy refers to the practice of adopting a critical perspective in the learning process, and yet it is not so easy to be critical since the basic hypothesis of these critical theories is that we can never be free from the prejudices developed in socialization. To promote critical capability, we need to address the paradox by exploring possibilities of liberating ourselves from the habituated thinking paradigms in which we are trapped in the process of socialization. To break or interrupt habituation or automation in cognition, 
we need something that is capable of disruption. Gee's (2015) hypothesis of literacy as a Secondary Discourse may offer a way of enabling such interruption:

The key point about secondary Discourses, however, is that they involve by definition, interaction with people with whom one is either not 'intimate,' with whom one cannot assume lots of shared knowledge and experience, or they involve interactions where one is being 'formal,' that is, taking on an identity that transcends the family or primary socializing group (p. 175).

English as a globally used language is "always a language in translation, a language of translingual use" (Pennycook 2008, p. 34). Although Pennycook calls English "the language of international capitalism", he also acknowledges English "not merely as a language of imperialism, but also as a language of opposition" (1994, p. 262). Canagarajah (1999) is most unequivocal in describing English as an instrument with "the liberatory potential of facilitating critical thinking" (p. 22) in a multicultural context. However, McKay (2002) argues that in encountering an alter culture, speakers are unlikely to end up knowing about the other's culture. Cross-cultural encounters can be reflexive, as people gain insight from the alter culture into their own culture. This is what she calls a cross-cultural contact zone. McKay (2002) goes on to say that a cross-cultural contact zone can be "a sphere of cross-culturality in EIL [English as an International Language] classrooms so that individuals gain insight into their own culture. These insights can then be shared in cross-cultural encounters undertaken in (inter)national contexts" (p. 100). However, there is a need for further studies to be carried out in order to identify the pedagogical value, if any, of Third Spaces and of contact zones and how they can develop and enhance the quality of literacy practices globally and locally.

To conclude, the English class, as a contact zone may not be merely confrontational, as Pratt (1991) once described. It can be a place where English is viewed as the significant other which offers different perceptions that can liberate nondominant groups from the constraints of their own culture; a place where people choose a perception not on the basis of simplistic identity politics that stresses differences only; and a place where people, sharing the benefits of differences, can develop the translingual ability to "translate, transpose and critically reflect on social, cultural and historical meanings" by taking part in a variety of critical literacy practices (Pennycook, 2008, p. 34). In an age of globalization when interaction between cultures has reached an unprecedented high frequency, translingual literacy practices, as shown in this chapter, enable disempowered individuals to transcend identity politics and to shuttle between dominant and nondominant languages and cultures thus giving them an opportunity to develop Third Spaces as a form of personal and group empowerment.

Discussion Questions

1. It has been argued that cultural literacy has cosmopolitan overtones. What does this mean and what do you think those overtones are?

2. The chapter takes the views that classrooms and different languages and cultures interact one with the other are zones of contact. What do you think sustains zones of contact and can you identify how such zones operate in migrant learners' knowledge of the world and their interactions with prescribed school curricula?

3. The Third Space, according to Gutiérrez (2008), is a celebration of local literacies. How can the school curriculum and, more specifically, you as an educator, can provide opportunities for the creation of Third Spaces where the aim is the celebration of your students' local literacies? 
Empowering Multilingual Learners Through Critical Liberating Literacy Practices in English-Dominated

\section{REFERENCES}

Alston-Abel, N. L., \& Berninger, V. W. (2018). Relationships between home literacy practices and school achievement: Implications for consultation and home-school collaboration. Journal of Educational \& Psychological Consultation, 28(2), 164-189. doi:10.1080/10474412.2017.1323222 PMID:30083040

Armour, W. S. (2001). This guy is Japanese stuck in a white man's body: A discussion of meaning making, identity slippage, and cross-cultural adaptation. Journal of Multilingual and Multicultural Development, 22(1), 1-18. doi:10.1080/01434630108666422

Barratt-Pugh, C. (2002). The socio-cultural context of literacy learning. In C. Barratt-Pugh \& M. Rohl (Eds.), Literacy learning in the early years (pp. 1-26). NSW, Australia: Allen \& Unwin.

Barrett, J. (1994). Why is English still the medium of education in Tanzanian secondary schools? Language, Culture, and Curriculum, 7(1), 3-16. doi:10.1080/07908319409525162

Bartlett, L. (2005). Identity work and cultural artefacts in literacy learning and use: A sociocultural analysis. Language and Education, 19(1), 1-9. doi:10.1080/09500780508668801

Barton, D., \& Hamilton, M. (1998). Local literacies: Reading and writing in one community. London, UK: Routledge.

Barton, D., Hamilton, M., \& Ivanic, R. (2000). Situated literacies: Reading and writing in one community. London, UK: Routledge.

Bernstein, B. (1999). Vertical and horizontal discourse: An essay. British Journal of Sociology of Education, 20(2), 157-173. doi:10.1080/01425699995380

Bhaktin, M. (1981). The dialogic imagination. Austin, TX: University of Texas Press.

Bourdieu, P. (1990). The logic of practice. San Francisco, CA: Stanford University Press.

Brandt, D. (2001).Literacy in American lives. Cambridge, UK: Cambridge University Press. doi:10.1017/ CBO9780511810237

Brandt, D., \& Clinton, K. (2002). Limits of the local: Expanding perspectives on literacy as a social practice. Journal of Literacy Research, 34(3), 337-356. doi:10.120715548430jlr3403_4

Burgess, A., \& Hamilton, M. (2011). Back to the future? Functional literacy and the new skills agenda. Retrieved from https://eprints.lancs.ac.uk/id/eprint/66608/1/Functional_Literacy_Discussion_Paper_ AB_MH.pdf

Burnett, C., \& Merchant, G. (2018). Literacy-as-event: Accounting for relationality in literacy research. Studies in the Cultural Politics of Education, 48(1), 1-12.

Canagarajah, S. (1999). Resisting linguistic imperialism in English teaching. Oxford, UK: Oxford University Press.

Christensen, T. (1994). Whose standard? Teaching standard English. In B. Bigelow, \& B. Peterson (Eds.), Rethinking our classrooms: Teaching for equity and justice (pp. 142-145). Milwaukee, WI: Rethinking Schools. 
Comber, B. (2010). Critical literacies in place: Teachers who work for just and sustainable communities. In J. Lavia, \& M. Moore (Eds.), Cross-cultural perspectives in policy and practice: Decolonizing community contexts (pp. 43-57). London, UK: Routledge.

Comber, B. (2015) Critical literacy and social justice. Journal of Adolescent \& Adult Literacy, 58(3), $358-363$.

Comber, B., Thompson, P., \& Wells, M. (2001). Critical literacy finds a "place": Writing and social action in a low-income Australian 2/3 classroom. The Elementary School Journal, 10(4), 451-464. doi:10.1086/499681

Comings, J. P. (2019). Functional literacy. Retrieved from https://www.oxfordbibliographies.com/view/ document/obo-9780199756797/obo-9780199756797-0032.xml

Cook, D., \& Klipfel, K. (2015). How do our students learn? References \& Users Quarterly, 55(1), 34-41. doi:10.5860/rusq.55n 1.34

Cope, B., \& Kalantzis, M. (2000). Multiliteracies: Literacy learning and the design of social futures. Melbourne, Australia: Macmillan Publishers.

Coulmas, F. (2018). An introduction to multilingualism: Language in a changing world. Oxford, UK: Oxford University Press.

Cruz, C. (2006). Testimonial narratives of queer street youth: Toward an epistemology of a brown body. International Journal of Qualitative Studies in Education: QSE, 14(5), 657-669. doi:10.1080/09518390110059874

Cummins, J. (2001). Language, power, and pedagogy: Bilingual children in the crossfire. Bristol, UK: Multilingual Matters.

Damber, U. (2012). Equity and models of literacy in a diverse world. Issues in Educational Research, 22(1), 36-46.

De Costa, P. (2016). The power of identity and ideology in language learning: Designer immigrants learning English in Singapore. Lansing, MI: Springer. doi:10.1007/978-3-319-30211-9

DeVoogd, G. L., \& McLaughlin, M. (2004). Critical literacy: Enhancing students' comprehension. New York, NY: Scholastic Inc.

Dyson, A. H. (1989). Multiple worlds of child writers: Friends learning to write. New York, NY: Teachers College Press.

Dyson, A. H. (1993). Social worlds of children learning to write in an urban primary school. New York, NY: Teachers College Press.

Dyson, A. H. (2001). Where are the childhoods in childhood literacy? An exploration in outer (school) space. Journal of Early Childhood Literacy, 1(1), 9-39. doi:10.1177/14687984010011002

Egbo, B. (2000). Gender, literacy, and life chances in sub-Saharan Africa. Bristol, UK: Multilingual Matters. 


\section{Empowering Multilingual Learners Through Critical Liberating Literacy Practices in English-Dominated}

Engeström, Y. (1996). Development as breaking away and opening up: A challenge to Vygotsky and Piaget. Swiss Journal of Psychology, 55, 126-132.

Engeström, Y. (2005). Developmental work research: Expanding activity theory in practice. Berlin, Germany: Lehmanns Media.

Ferguson, C. A. (1959). Diglossia. Word, 14(2), 47-56.

Freire, P. (1972). Pedagogy of the oppressed. New York, NY: Seabury.

Freire, P., \& Macedo, D. (1987). Literacy: Reading the word and the world. South Hadley, MA: Bergin \& Garve.

Gee, J. P. (2015). Social linguistics and literacies: Ideology in discourses (5th ed.). Bristol, PA: The Falmer Press. doi:10.4324/9781315722511

Gonzalez, N., Moll, L., \& Amanti, C. (2005). Funds of knowledge: Theorizing practices in households, communities, and classrooms. Rahway, NJ: Lawrence Erlbaum.

Graff, H. (1994). Literacy, myths and legacies: Lessons from the history of literacy. In L. T. Verhoeven (Ed.), Functional literacy: Theoretical issues and educational implications (pp. 231-322). Amsterdam, The Netherlands: John Benjamins. doi:10.1075wll.1.05gra

Gray, W. S. (1956). The teaching of reading and writing. Paris, France: UNESCO.

Gregory, E., \& Williams, A. (2000). City literacies: Learning to read across generations and cultures. London, UK: Routledge.

Gutiérrez, K. (2018). Developing a sociocritical literacy in the Third Space. Reading Research Quarterly, 43(2), 148-164. doi:10.1598/RRQ.43.2.3

Gutiérrez, K., \& Rogoff, B. (2003). Cultural ways of learning: Individual traits or repertoires of practice. Educational Researcher, 32(5), 19-25. doi:10.3102/0013189X032005019

Hamers, J. F., \& Blanc, M. H. A. (2000). Bilinguality and bilingualism (2nd ed.). Cambridge, UK: Cambridge University Press. doi:10.1017/CBO9780511605796

Hammer, J. (2005). Exploring literacy with infants from a sociocultural perspective. New Zealand Journal of Teachers'. Work (Reading, Mass.), 2(2), 70-75.

Heath, S. B. (1983). Ways with words: Language, life and work in communities and classrooms. Cambridge, UK: Cambridge University Press. doi:10.1017/CBO9780511841057

Higgins, C. (2009). English as a local language: Post-colonial identities and multilingual practices. Bristol, UK: Multilingual Matters. doi:10.21832/9781847691828

Horner, B., \& Lu, M. (2007). Resisting monolingualism in English. In V. Ellis, C. Fox, \& B. Street (Eds.), Rethinking English in schools: A new and constructive stage (pp. 65-87). New York, NY: Longman.

Janks, H. (2010). Literacy and power. New York, NY: Routledge. 
Janks, H., Dixon, K., Ferreira, A., Granville, S., \& Newfield, D. (2014). Doing critical literacy: Texts and activities for students and teachers. London, UK: Routledge.

Kalman, J. (1999). Writing on the plaza: Mediated literacy practice among scribes and clients in Mexico City. Cresskill, NJ: Hampton.

Kashina, K. (1994). The dilemma of standard English in Zambia: Pedagogical, educational and sociocultural considerations. Language, Culture, and Curriculum, 7(1), 17-28. doi:10.1080/07908319409525163

Lee, C. (2007). Culture, literacy and learning: Taking Bloom in the midst of the whirlwind. New York, NY: Teachers College Press.

Leland, C., Harste, J., \& Huber, K. (2005). Out of the box: Critical literacy in a first-grade classroom. Language Arts, 82(4), 257-268.

Levine, K. (1982). Functional literacy: Fond illusions and false economies. Harvard Educational Review, 52(3), 249-266. doi:10.17763/haer.52.3.77p7168115610811

Luke, A. (2012). Critical literacy: Foundational notes. Theory into Practice, 51(1), 411.

McDaniel, C. A. (2006). Critical literacy. Bern, Switzerland: Peter Lang.

McKey, S. L. (2002). Teaching English as an international language: Rethinking goals and perspectives. Oxford, UK: Oxford University Press.

Moje, E. B., Ciechanowski, K. M., Kramer, K., Ellis, L., Carrillo, R., \& Collazo, T. (2004). Working toward third space in content area literacy: An examination of everyday funds of knowledge and discourse. Reading Research Quarterly, 39(1), 38-70. doi:10.1598/RRQ.39.1.4

Morrell, E., \& Duncan-Andrade, J. (2002). Promoting academic literacy with urban youth through engaging Hip-hop culture. English Journal, 91(July), 88-92. doi:10.2307/821822

Nag, S., Vagh, S., Dulay, K., \& Snowling, M. (2019). Home language, school language and children's literacy attainment: A systematic review of evidence from low- and middle-income countries. Review of Education, 7(1), 91-150. doi:10.1002/rev3.3132

Naldic. (2019). Bilingualism and second language acquisition. Retrieved from https://www.naldic.org. uk/eal-teaching-and-learning/outline-guidance/bilingualism/

Nash, K., Howard, J., Miller, E., Boutte, G., Johnson, G., \& Reid, L. (2018). Critical racial literacy in homes, schools, and communities: Propositions for early childhood contexts. Contemporary Issues in Early Childhood, 19(3), 256-273. doi:10.1177/1463949117717293

Neal, J. C., \& Kelly, P. R. (1999). The success of reading recovery for English language learners and descubriendo la lectura for bilingual students in California. Literacy, Teaching, and Learning, 4(2), 81-108.

Ochoa, G., McDonald, S., \& Monk, N. (2018). Adapting open-space learning techniques to teach cultural literacy. Open Cultural Studies, 2(1), 510-519. doi:10.1515/culture-2018-0046

Oecd.org. (2019). PISA. Retrieved from http://www.oecd.org/pisa/ 


\section{Empowering Multilingual Learners Through Critical Liberating Literacy Practices in English-Dominated}

Olson, D. R. (2000). Curriculum as a multi-storied process. Canadian Journal of Education, 25(3), 169-187. doi:10.2307/1585952

Olson, D. R. (2017). The languages of instruction: The literate bias of schooling. In R. C. Anderson, R. J. Spiro, \& W. E. Montague (Eds.), Schooling and the acquisition of knowledge (pp. 65-89). Hillsdale, NJ: Lawrence Erlbaum. doi:10.4324/9781315271644-7

Olson, D. R., \& Torrance, N. G. (2017). Literacy and cognitive development: A conceptual transformation in the early school years. In S. Meadows (Ed.), Developing thinking: Approaches to children's cognitive development (pp. 102-121). London, UK: Routledge. doi:10.4324/9781315213323-7

Pahl, K., \& Burnett, C. (2016). Literacies in homes and communities. In K. Hall, T. Cremin, B. Comber, \& L. C. Moll (Eds.), International handbook of research on children's literacy, learning, and culture (pp. 3-14). Chichester, UK: John Wiley \& Sons.

Parajuli, P., \& Enslin, E. (1990). From learning literacy to regenerating women's space: A story of women's empowerment in Nepal. Convergence (Toronto), 23(1), 44-56.

Pennycook, A. (1994). The cultural politics of English as an international language. London, UK: Longman.

Pennycook, A. (1998). English and the discourses of colonialism. London, UK: Routledge.

Pennycook, A. (2008). English as a language always in translation. Journal of English Studies, 12(1), 33-47. doi:10.1080/13825570801900521

Perfetti, C. A., \& Harris, L. N. (2017). Learning to read English. In L. Verhoeven, \& C. A. Perfetti (Eds.), Learning to read across languages and writing systems (pp. 347-370). Cambridge, UK: Cambridge University Press. doi:10.1017/9781316155752.014

Phillipson, R. (2007). English in Europe: Threat or promise? In M. N. Craith (Ed.), Language, power, and identity politics (pp. 65-82). Basingstoke, UK: Palgrave Macmillan. doi:10.1057/9780230592841_4 Phillipson,R.(2013).Linguisticimperialismcontinued.London,UK:Routledge.doi:10.4324/9780203857175 Pratt, M. L. (1991). Arts of the contact zone. Profession, 91, 33-40.

Prinsloo, M., \& Breier, M. (Eds.). (1996). The social uses of literacy. Amsterdam, The Netherlands: J. Benjamin. doi:10.1075wll.4

Qu, W. (2011). English, identity and critical literacy. Changing English, 18(3), 297-307. doi:10.1080/ 1358684X.2011.602837

Rabušicová, M., \& Oplatková, P. (2010). Functional literacy in people's lives. Journal of Pedagogy, 1(2), 29-51. doi:10.2478/v10159-010-0008-3

Rasool, E. (1996). Unveiling the heart of fear. In W. James, D. Caliguire, \& K. Cullinan (Eds.), Now that we are free: Coloured communities in a democratic South Africa (pp. 54-68). Cape Town, South Africa: IDASA.

Richardson, E. (2006). Hiphop Literacies. London, UK: Routledge. doi:10.4324/9780203391105 
Ryan, C. (2010). How do you spell family? Literacy, heteronormativity, and young children of lesbian mothers (Unpublished doctoral dissertation). The Ohio State University, Ohio.

Saxe, J. G. (1863). The blind men and the elephant; John Godfrey Saxe's version of the famous Indian legend. New York, NY: Whittlesey House.

Scribner, S., \& Cole, M. (1981). The psychology of literacy. Cambridge, MA: Harvard University Press. doi:10.4159/harvard.9780674433014

Stables, A. (2003). Environmental education and the arts-science divide: The case for a disciplined environmental literacy. In A. Winnett, \& A. Warhust (Eds.), Towards an environment research agenda (pp. 49-59). London, UK: Palgrave Macmillan. doi:10.1057/9780230536814_4

Street, B., \& Lefstein, A. (2007). Literacy: An advanced resource book. London, UK: Routledge. doi:10.4324/9780203463994

Street, B., \& Street, J. (1995). The schooling of literacy. In P. Murphy, M. Selinger, J. Bourne, \& M. Briggs (Eds.), Subject learning in the primary curriculum (pp. 179-183). London, UK: Routledge.

Street, B. V. (1984). Literacy in theory and practice. New York, NY: Cambridge University Press.

Street, B. V. (1995). Social literacies. Critical approaches to literacy in development, ethnography and education. Harlow, UK: Longman.

Street, B. V. (Ed.). (2001). Literacy and development. London, UK: Routledge.

Street, B. V. (2013). New literacy studies. In M. Grenfell, D. Bloome, C. Hardy, K. Pahl, J. Rowsell, \& B. Street (Eds.), Language, ethnography, and education (pp. 33-55). London, UK: Routledge.

Street, B. V. (2017). New literacies, new times: Developments in literacy studies. In B.V. Street, \& S. May (Ed.), Literacies and Language Education (pp. 1-13) London, UK: Springer International Publishing.

Vickery, A. E. (2016). 'I know what you are about to enter': Lived experiences as the curricular foundation for teaching citizenship. Gender and Education 28(6), 725-741.

Villegas, A. M. (1988). School failure and cultural mismatch: Another view. The Urban Review, 20(4), 253-265. doi:10.1007/BF01120137

Vygotsky, L. S. (1980). Mind in society: The development of higher psychological processes. Cambridge, MA: Harvard University Press. doi:10.2307/j.ctvjf9vz4

Wallace, C. (2002) Local literacies and global literacies. In D. Black, \& D. Cameron (Eds.), Globalization and language teaching (pp. 101-114). London, UK: Routledge.

Wallace, C. (2003). Critical reading in language education. London, UK: Palgrave Macmillan. doi:10.1057/9780230514447

White, S. J., Warrington, K. L., McGowan, V. A., \& Paterson, K. B. (2015). Eye movements during reading and topic scanning: Effects of word frequency. Journal of Experimental Psychology. Human Perception and Performance, 41(1), 233-248. doi:10.1037/xhp0000020 PMID:25528014 
Whitford, V., \& Titone, D. (2016). Eye movements and the perceptual span during first- and secondlanguage sentence reading in bilingual older adults. Psychology and Aging, 31(1), 58-70. doi:10.1037/ a0039971 PMID:26866589

Wohlwend, K. E., \& Lewis, C. (2011). Critical literacy, critical engagement, and digital technology: Convergence and embodiment in global spheres. In D. Lapp, \& D. Fisher (Eds.), Handbook of research on teaching English language arts (3rd ed., pp. 188-194). Mahwah, NJ: Lawrence Erlbaum.

Wray, D. (1997). Research into teaching of reading: A 25-year debate. In K. Watson, C. Modgill, \& S. Modgill (Eds.), Education dilemmas: Debates and diversity. Quality in education (Vol. 4, pp. 118-126). London, UK: Cassell.

\section{KEY TERMS AND DEFINITIONS}

Autonomous Model of Literacy: A model underpinned by the assumption that literacy in itself (i.e., autonomously) has effects on other social and cognitive practices that are neutral and universal.

Critical Literacy: Learning to read and write as part of the process of becoming conscious of one's experience as historically constructed within specific power relations. Critical literacy moves the reader's focus away from the "self" in critical reading to the interpretation of texts in different environmental and cultural contexts.

Cultural Literacy: The ability to understand and participate fluently in a given culture, normally a culture different from one's own.

Expansive Learning: The capacity of individuals involved in an activity to interpret and expand the definition of the object of activity and respond to it in increasingly enriched ways. Expansive learning involves the creation of new knowledge and new practices for a newly emerging activity: that is, learning embedded in and constitutive of qualitative transformation of the entire activity system.

Functional Literacy: Knowledge of reading and writing which enables individuals to acquire basic cognitive skills to accomplish practical ends in culturally specific settings.

Ideological Model of Literacy: A model that posits that literacy is a social practice, not simply a technical and neutral skill but it is about the ways in which people address reading and writing rooted in conceptions of knowledge, identity, and being.

Multilingualism: The ability of an individual speaker or a community of speakers to communicate effectively in three or more languages.

Socio-critical Literacy: The capacity to historicize literacy that privileges and is contingent upon students' sociohistorical lives, both proximally and distally.

Third Space: A poststructuralist sociolinguistic theory of identity and community realized through language or education. Third Space theory explains the uniqueness of each person, actor or context as a "hybrid."

Zone of Contact: Social spaces where cultures meet, clash, and grapple with each other, often in contexts of highly asymmetrical relations of power. 
Empowering Multilingual Learners Through Critical Liberating Literacy Practices in English-Dominated

\section{APPENDIX: SUGGESTED FURTHER READINGS}

1. Janks, H., Dixon, K., Ferreira, A., Granville, S., \& Newfield, D. (2014) Doing critical literacy. Texts and activities for students and teachers. Oxon, UK: Routledge.

This book offers a collection of activities aimed at raising students' awareness of the use of language in different aspects of everyday life by means of a series of tasks around real-world texts to discuss how authors position themselves to create different responses from readers.

2. Vasquez, V., Tate, S. \& Harste, J. (2013) Negotiating critical literacies with teachers. Theoretical foundations and pedagogical resources for pre-service and in-service contexts. Oxon, UK: Routledge.

This book examines critical literacy by explaining and illustrating opportunities for pre-service and in-service teachers to "live critical literacies" through experiencing first-hand what it is like to be a learner where the curriculum is built around teachers' own inquiry questions, passions, and interests.

3. Edwards, V. (2009) Learning to be literate. Multilingual perspectives. Bristol, UK: Multilingual Matters.

This volume offers a comprehensive, accessible overview of bilingualism, biliteracy, and language education around the world. The inclusion of activities and discussion points at the end of each chapter makes the book ideal for core reading at both undergraduate and postgraduate level. 